\title{
Interference of Long-Distance Movement of Grapevine berry inner necrosis virus in Transgenic Plants Expressing a Defective Movement Protein of Apple chlorotic leaf spot virus
}

\author{
N. Yoshikawa, Y. Saitou, A. Kitajima, T. Chida, N. Sasaki, and M. Isogai
}

Faculty of Agriculture, Iwate University, Ueda 3-18-8, Morioka 020-8550, Japan.

Accepted for publication 2 December 2005.

\begin{abstract}
Yoshikawa, N., Saitou, Y., Kitajima, A., Chida, T., Sasaki, N., and Isogai, M. 2006. Interference of long-distance movement of Grapevine berry inner necrosis virus in transgenic plants expressing a defective movement protein of Apple chlorotic leaf spot virus. Phytopathology 96:378-385.

Transgenic Nicotiana occidentalis plants expressing a movement protein (P50) and partially functional deletion mutants ( $\Delta \mathrm{A}$ and $\Delta \mathrm{C})$ of the Apple chlorotic leaf spot virus (ACLSV) showed resistance to Grapevine berry inner necrosis virus (GINV). The resistance is highly effective and GINV was below the level of detection in both inoculated and uninoculated upper leaves. In contrast, GINV accumulated in inoculated and uninoculated leaves of nontransgenic (NT) plants and transgenic plants expressing a dysfunctional mutant $(\Delta \mathrm{G})$. On the other hand, in some plants of a transgenic plant line expressing a deletion mutant $\left(\Delta \mathrm{A}^{\prime}\right.$,

lated leaves, but not move into uninoculated leaves. In a tissue blot hybridization analysis of $\Delta \mathrm{A}^{\prime}$-plants inoculated with GINV, virus could be detected in leaf blade, midribs, and petiole of inoculated leaves, but neither in stems immediately above inoculated leaves nor in any tissues of uninoculated leaves. Immunohistochemical analysis of GINV-inoculated leaves of $\Delta \mathrm{A}^{\prime}$-plants showed that GINV could invade into phloem parenchyma cells through bundle sheath of minor veins, suggesting that the long-distance transport of GINV might be inhibited between the phloem cells and sieve element (and/or within sieve element) rather than bundle sheath-phloem interfaces. Immunogold electron microscopy using an anti-P50 antiserum showed that P50 accumulated on the parietal layer of sieve elements and on sieve plates. The results suggested that resistance in P50-transgenic plants to GINV is due to the interference of both longdistance and cell-to-cell movement of the virus.
\end{abstract} deletion of the C-terminal 42 amino acids), GINV could spread in inocu-
Apple chlorotic leaf spot virus (ACLSV) has flexuous filamentous particles, approximately 740 to $760 \mathrm{~nm}$ in length and is the type species of the genus Trichovirus $(8,9,19,22,36)$. The $50-\mathrm{kDa}$ protein (P50) encoded by open reading frame 2 of ACLSV genome is a movement protein (MP), which has the following characteristics: (i) it localizes to plasmodesmata of infected and transgenic plant cells (35), (ii) it can spread from the cells that initially produce it into neighboring cells (24), (iii) it enables cell-to-cell trafficking of green fluorescent protein (GFP) when P50 and GFP are co-expressed in leaf epidermis (24), (iv) it induces the production of tubular structures protruding from the surface of protoplasts (24), and (v) it binds to single-stranded nucleic acids (12).

Transgenic plants expressing viral MPs are reported to be resistant to homologous and heterologous viruses and the phenomenon is called MP-derived resistance $(1,2,5,15,18,25)$. Recently, we reported that transgenic Nicotiana occidentalis plants expressing a functional ACLSV P50 show specific resistance to infection with Grapevine berry inner necrosis virus (GINV, a member of the genus Trichovirus) (34), but not to infection with Apple stem grooving virus (genus Capillovirus) and Apple stem pitting virus (genus Foveavirus) (33). The resistance of transgenic plants expressing P50 (P50-plant) to GINV is highly effective, and GINV has not been detected in either inoculated or upper uninoculated leaves by an enzyme-linked immunosorbent assay (ELISA) (33). The analysis of the interactions between P50 and GINV-MP (P39) in P50-plants and nontransgenic (NT) plants showed that a functional P50 specifically interferes with the intracellular and inter-

Corresponding author: N. Yoshikawa; E-mail address: yoshikawa@iwate-u.ac.jp

DOI: 10.1094/PHYTO-96-0378

(C) 2006 The American Phytopathological Society cellular trafficking and tubule-inducing activity of P39 and vice versa (11). It was suggested that the resistance was not due to gene silencing because the proteins, not mRNAs, were involved in the mutual interference of the functions of P50 and P39 (11). Therefore, it was concluded that the resistance of P50-plants against GINV is mediated through interaction between P50 and P39, i.e., P50 in transgenic plants blocks the functions of P39, and consequently, the cell-to-cell movement of GINV is inhibited in tissues expressing P50 (11).

Transgenic plants expressing the P50-deletion mutants, $\Delta \mathrm{A}$ and $\Delta C$, which retained movement function (24), were resistant to GINV, whereas transgenic plants expressing a dysfunctional P50 mutant $(\Delta \mathrm{G})$ did not show any resistance to the virus (11). In this paper, we report that a transgenic plant line expressing $\Delta \mathrm{A}^{\prime}$ (deletion of the C-terminal 42 amino acids) allowed GINV to spread in inoculated leaves, but not into upper leaves, indicating that $\Delta \mathrm{A}^{\prime}$ expressed in transgenic plants interferes with the long-distance movement of GINV. We also showed that the block in systemic movement of GINV in $\Delta \mathrm{A}^{\prime}$-plants may occur at the boundary between phloem cells and sieve elements and/or within sieve tubes, not in the bundle sheath-phloem interface.

\section{MATERIALS AND METHODS}

Plants expressing P50 and its truncated derivatives. $N$. occidentalis plants expressing P50 (line d-5) and its truncated derivatives $(\Delta \mathrm{A}$ [line $\mathrm{A}-3], \Delta \mathrm{C}$ [line $\mathrm{C}-3]$, and $\Delta \mathrm{G}$ [line $\mathrm{G}-23])(11,33)$ were used in this study. Another $N$. occidentalis deletion mutant, $\Delta \mathrm{A}^{\prime}$, which has amino acids 416 through 457 deleted, was constructed as described previously (33). Transgenic plant line A'-5, which expresses the $\Delta \mathrm{A}^{\prime}$ deletion mutant, was used in this study. Northern blot hybridization and immunoblot assays of R1 seed- 
lings of transgenic plants were conducted to compare the expression level of mRNAs and proteins among lines d-5, A-3, C-3, G-23, and A'-5 as described below.

Total RNA was extracted from transgenic plant leaves $(0.1 \mathrm{~g})$ according to Verwoerd et al. (30). LiCl-insoluble RNA was electrophoresed in $1 \%$ agarose gel containing formaldehyde and transferred to a Hybond- $\mathrm{N}^{+}$membrane (Amersham, Tokyo). A negative-strand RNA probe of full-length 50KP gene was prepared from a cDNA clone using a digoxigenin RNA labeling kit (Roche Diagnostics, Tokyo, Japan). Prehybridization, hybridization, and chemiluminescent detection were conducted according to the protocols supplied by Roche Diagnostics.

Total proteins were extracted from leaves $(0.1 \mathrm{~g})$, electrophoresed in a sodium dodecyl sulfate-polyacrylamide gel, and then analyzed by immunoblotting using an anti-P50 antiserum as described previously $(23,33)$.

Mechanical inoculation of GINV. Two grams of GINVinfected Chenopodium quinoa leaves was homogenized in $10 \mathrm{ml}$ of $0.1 \mathrm{M}$ Tris- $\mathrm{HCl}\left(\mathrm{pH} \mathrm{7.2)}\right.$ and $0.01 \mathrm{M} \mathrm{MgCl}_{2}$, and the homogenates were used for inoculation.

Kanamycin-resistant R1 seedlings of transgenic $N$. occidentalis plants (50KP, $\Delta \mathrm{A}^{\prime}, \Delta \mathrm{A}, \Delta \mathrm{C}$, and $\Delta \mathrm{G}$ ) were grown to the six- to seven-leaf stage in pots. Before virus inoculation, the seedlings were analyzed by immunoblot analysis to confirm the expression of the protein, and only plants expressing the protein were used for inoculation tests. Three leaves per plant were mechanically inoculated with GINV, and inoculated plants were grown in a growth chamber and observed for symptoms. Ten plants per transgenic line were assayed in each infection test, and the experiments were repeated three times.

Analyses of inoculated plants. Inoculated and upper uninoculated leaves of $N$. occidentalis plants were collected at 14 and 21 days postinoculation (dpi), respectively, and the virus accumulation was assayed by ELISA using an anti-GINV antiserum as described previously (33).

Virus infection was also analyzed by a direct tissue immunoblotting (26). Fresh whole leaves harvested at 7 dpi (inoculated leaves) and 14 dpi (upper uninoculated leaves) were placed between two layers of No. 2 filter paper. Blots were made by gently striking the leaves with a rubber hammer. The paper was rinsed in $2 \%$ Triton X-100 for 30 min with gentle shaking to remove residual green color and then in phosphate-buffered saline with Tween (PBST)-milk (10 mM NaPO4, pH 7.2, 0.9\% NaCl, 0.1\% Tween, and $3 \%$ skim milk) for $30 \mathrm{~min}$. The paper was incubated with an antiserum against GINV as a primary antibody, washed with PBST-milk, and incubated with a goat anti-rabbit immunoglobulin $\mathrm{G}(\mathrm{IgG})$ conjugated with alkaline phosphatase as a secondary antibody. Nitroblue tetrazolium-5-bromo-4-chloro-3-indolylphosphate toluidinium (NBT-BCIP) was used for color developing.

For tissue blot hybridization analysis, a negative-strand RNA probe was prepared from a cDNA clone of GINV (nucleotides 825 to 2469 of the genome) (34) as described previously. Leaf blades, midribs, and petioles from inoculated and upper uninoculated leaves were cut by a razor blade, and the cut faces were directly touched to a Hybond- $\mathrm{N}^{+}$membrane. In this blotting, leaf blades were rolled and then cut by razor before blotting. Midribs ( $8 \mathrm{~mm}$ long) were cut vertically, and cut faces of two pieces were blotted. The petioles and stems, immediately above the inoculated leaves, were cut horizontally, and the cut face was contacted onto a membrane. Prehybridization, hybridization, and chemiluminescent detection were conducted according to the protocols supplied by Roche Diagnostics.

Immunohistochemical analysis. Leaf pieces $\left(5 \mathrm{~mm}^{2}\right)$ from NT and transgenic $N$. occidentalis plants (50KP and $\left.\Delta \mathrm{A}^{\prime}\right)$ inoculated with GINV were excised and fixed in $4 \%$ formaldehyde in $0.1 \mathrm{M}$ Na-phosphate buffer ( $\mathrm{pH} 7.5)$ at $4^{\circ} \mathrm{C}$ overnight. The samples were dehydrated, treated in Histo-clear (National Diagnostics, UK), and embedded in paraffin (Paraplast Embedding Media, Sigma,
Tokyo, Japan). Preparations of thin sections $(10 \mu \mathrm{m})$ were carried out as described by Karyeija et al. (13). Thin sections were initially incubated in PBS containing $4 \%$ bovine serum albumin (BSA) for $30 \mathrm{~min}$ and then treated with an antibody against GINV (dilution 1:100) for $3 \mathrm{~h}$ at room temperature. After washing with PBS, the samples were incubated with a goat anti-rabbit IgG conjugated with alkaline phosphatase. After washing with PBS, samples were stained with a fuchsin substrate solution as described by Rajamaki and Valkonen $(20,21)$ and observed by a light microscope.

Confocal laser scanning microscopy. Examinations of transgenic plant leaves expressing P50 fused to GFP (EGFP) were conducted under a confocal laser scanning microscope (Leica CLSM; Leica, Wetzlar, Germany) using the following conditions: excitation filter BP488, beamsplitter TK510, and emission filter BP540 as described previously (35).

Immunogold electron microscopy. Leaf pieces, $1 \times 10 \mathrm{~mm}$, from transgenic $N$. occidentalis plants expressing $\mathrm{P} 50, \Delta \mathrm{A}, \Delta \mathrm{A}^{\prime}$, and $\Delta \mathrm{G}$ proteins, and ACLSV-infected $C$. quinoa plants were fixed in $2 \%$ paraformaldehyde plus $0.5 \%$ glutaraldehyde overnight. The samples were dehydrated through ethanol series, infiltrated in a graded series of LR White resin at low temperature $\left(-20^{\circ} \mathrm{C}\right)$, and polymerized at $58^{\circ} \mathrm{C}$ for 16 to $20 \mathrm{~h}$ as described pre-
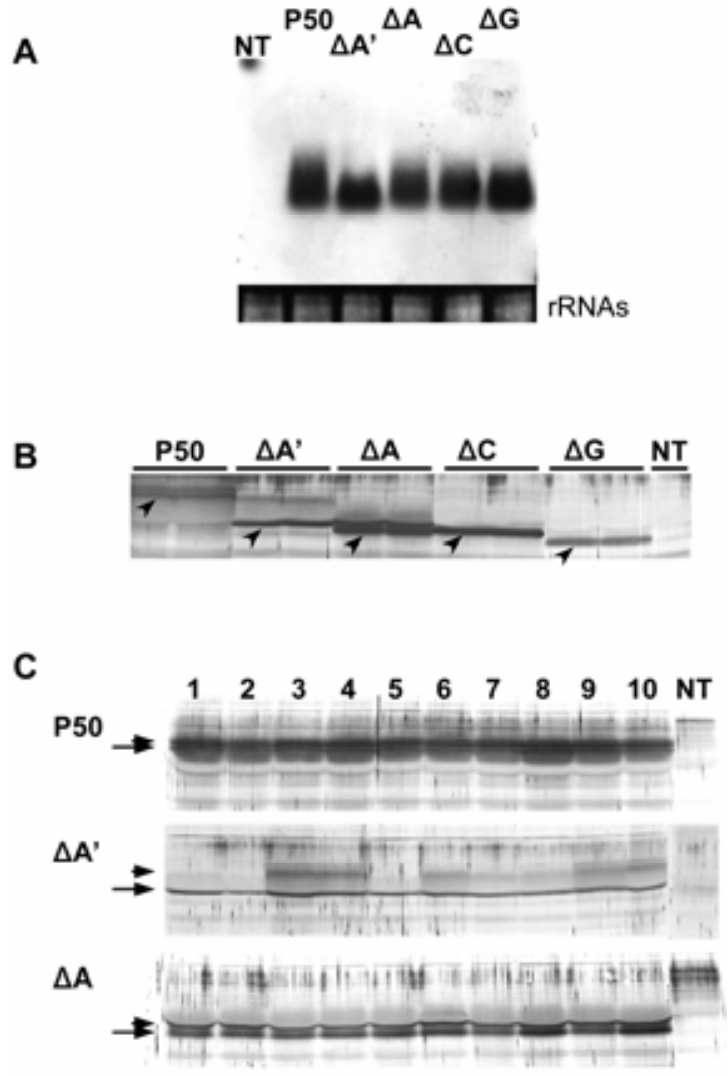

Fig. 1. Analyses of transgenic Nicotiana occidentalis plants expressing P50 and $\mathrm{P} 50$ deletion mutants $\left(\Delta \mathrm{A}^{\prime}, \Delta \mathrm{A}, \Delta \mathrm{C}\right.$, and $\left.\Delta \mathrm{G}\right)$ of Apple chlorotic leaf spot virus (ACLSV). A, Northern blot analysis of RNA from a leaf sample of nontransgenic plant (lane NT) and leaf samples from kanamycin-resistant R1 seedlings of transgenic plants expressing P50 (lane 1), $\Delta \mathrm{A}^{\prime}$ (lane 2), $\Delta \mathrm{A}$ (lane 3), $\Delta \mathrm{C}$ (lane 4), and $\Delta \mathrm{G}$ (lane 5). B, Immunoblot analyses of leaf samples from kanamycin-resistant $\mathrm{R} 1$ seedlings of transgenic plants expressing P50, $\Delta \mathrm{A}^{\prime}, \Delta \mathrm{A}, \Delta \mathrm{C}$, and $\Delta \mathrm{G}$. Total proteins from $2.5 \mathrm{mg}$ of leaf tissues were loaded per lane. Arrowheads indicate the positions of expressed P50 and P50 deletion mutants. C, Immunoblot analyses of leaf samples from kanamycin-resistant $\mathrm{R} 1$ seedlings of transgenic plant expressing $\mathrm{P} 50, \Delta \mathrm{A}^{\prime}$, and $\Delta \mathrm{A}$. Lanes 1 to 10 , leaf samples from 10 individual transgenic plants. Lane NT, leaf samples from a nontransgenic plant. Arrows indicate the positions of P50, $\Delta \mathrm{A}$, and $\Delta \mathrm{A}$. Arrowheads indicate the positions of the phosphorylated forms of P50, $\Delta \mathrm{A}^{\prime}$, and $\Delta \mathrm{A}$. 
viously (35). Thin sections (98 $\mathrm{nm}$ ) were mounted on formvarcoated nickel grids and incubated in $2 \%$ BSA in $0.15 \mathrm{M} \mathrm{NaCl}$, $0.1 \mathrm{M}$ phosphate buffer, $\mathrm{pH} 7.4$ (PBS), for $45 \mathrm{~min}$. Sections were then treated with an antiserum against P50 diluted with 1:500 in PBS containing $0.5 \%$ BSA for 90 to $120 \mathrm{~min}$. After washing with PBS containing $0.1 \%$ BSA, the grids were incubated in a goat anti-rabbit IgG coupled to $10 \mathrm{~nm}$ colloidal gold (Zymed Laboratories, CA) for 45 to $60 \mathrm{~min}$. The sections were stained with $1 \%$ uranyl acetate. All sections were viewed with a Hitachi H-800 (Tokyo, Japan) electron microscope.

\section{RESULTS}

Analysis of the transgenic plants expressing P50 and its truncated derivatives. R1 seedlings from transgenic plants used in this study segregated 3:1 for resistance to kanamycin. Northern

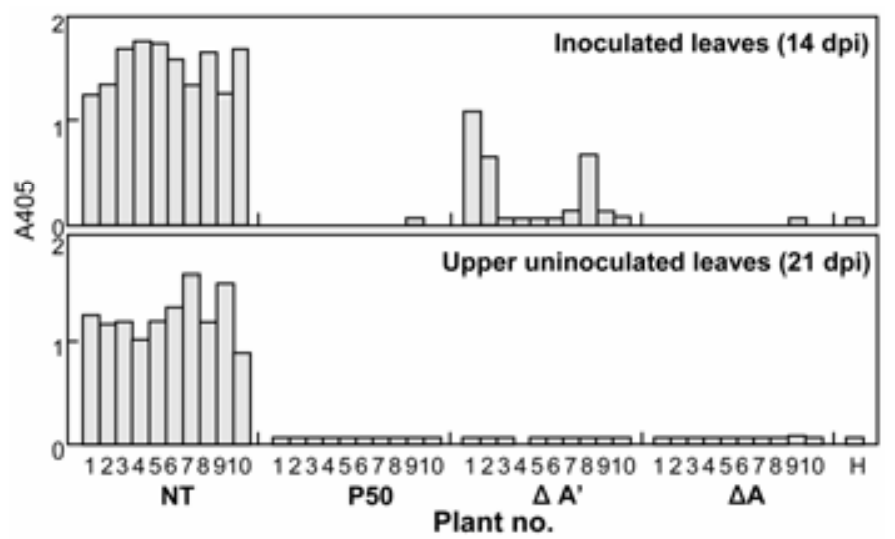

Fig. 2. Virus accumulation in nontransgenic (NT) and transgenic Nicotiana occidentalis plants (P50, $\Delta \mathrm{A}^{\prime}$, and $\Delta \mathrm{A}$ ) inoculated with Grapevine berry inner necrosis virus (GINV). Inoculated and upper uninoculated leaves from each of 10 plants were collected at 14 days postinoculation (dpi) and $21 \mathrm{dpi}$, respectively, and GINV accumulation was determined by an enzyme-linked immunosorbent assay. $\mathrm{H}$, a healthy leaf sample. blot and immunoblot analyses of kanamycin-resistant R1 seedlings showed that mRNAs and proteins of P50 and its truncated derivatives were expressed in all samples from transgenic plant lines d-5, A'-5, A-3, C-3, and G-23. No large differences in the amount of mRNAs and the expressed proteins were noted among these lines (Fig. 1A and B).

In a previous report, we showed that transgenic $N$. occidentalis plants expressing P50 complemented the systemic spread of the P50-deficient ACLSV mutants (pStuStop and $\mathrm{p} \Delta$ StuNhe) (33). When these P50-deficient mutants were inoculated onto A'-5, $\Delta \mathrm{A}^{-}$ $3, \Delta \mathrm{C}-3$, and $\Delta \mathrm{G}-23$ plants by particle bombardments, no complementation of the movement of P50-deficient virus was found in inoculated or uninoculated upper leaves of these transgenic plants expressing P50 deletion mutants (data not shown), though $\Delta \mathrm{A}^{\prime}$, $\Delta \mathrm{A}$, and $\Delta \mathrm{C}$, but not $\Delta \mathrm{G}$, retained the activities for localization to plasmodesmata, cell-to-cell trafficking, and tubule formation on surface of protoplasts (24; unpublished data).

Before GINV was inoculated, 10 individual plants of transgenic lines d-5, A'-5, or A-3 were analyzed by an immunoblot analysis. P50 was detected as diffuse bands (Fig. 1C), suggesting that P50 expressed in transgenic plants is phosphorylated as shown in infected leaves (23). Similarly, $\Delta \mathrm{A}$ protein in all transgenic plant leaves and $\Delta \mathrm{A}^{\prime}$ protein in some plants were seen as two bands (Fig. 1C). The slower migrating bands were suggested to be phosphorylated because the incubation of the protein samples with alkaline phosphatase resulted in the change of the electrophoretic mobility from the slower migrating band to the faster migrating band (data not shown). There were no differences in the amount of the expressed proteins among individual plants of transgenic lines d-5, A'-5, or A-3 (Fig. 1C).

Response of the transgenic plants expressing P50 and P50 deletion mutants to GINV infection. When transgenic (50KP, $\Delta \mathrm{A}^{\prime}$, and $\Delta \mathrm{A}$ ) and NT $N$. occidentalis plants (10 individual plants per line) were inoculated with GINV, the transgenic plants did not develop detectable symptoms in either the inoculated or upper uninoculated leaves. In contrast, the GINV-inoculated NT-plants showed chlorotic spots and mosaic symptoms in uninoculated leaves. ELISA of extracts from P50- and $\Delta \mathrm{A}$-plants inoculated

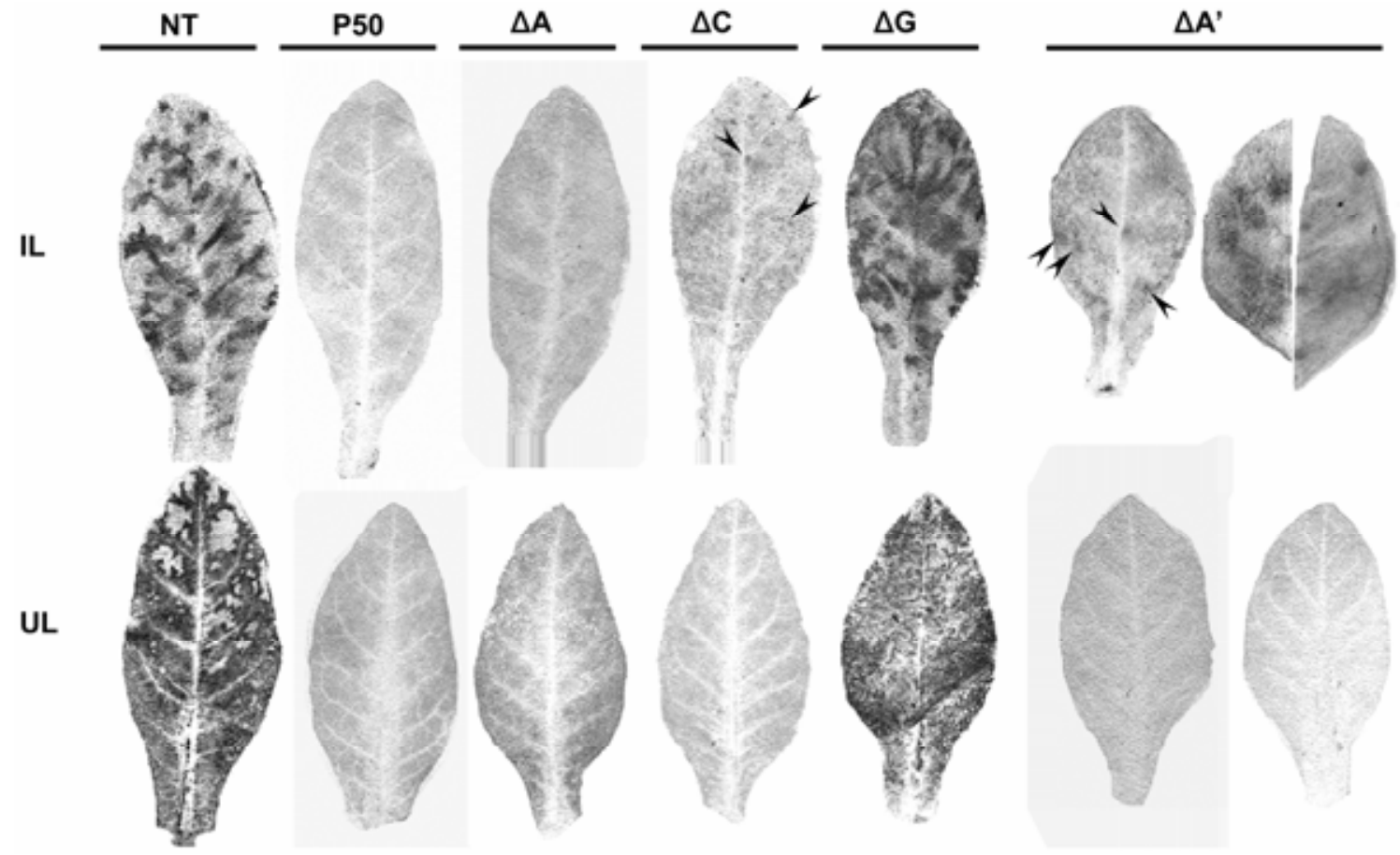

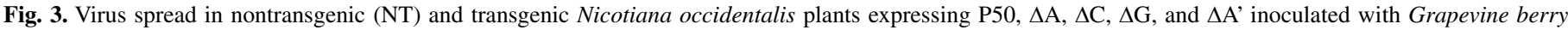

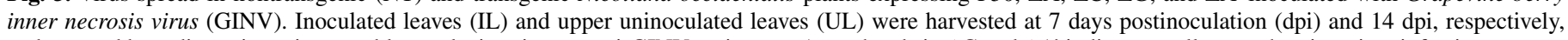
and assayed by a direct tissue immunoblot analysis using an anti-GINV antiserum. Arrowheads in $\Delta \mathrm{C}$ and $\Delta \mathrm{A}^{\prime}$ indicate small spots showing virus infection. 
with GINV using an anti-GINV antiserum indicated that no detectable virus accumulated in inoculated leaves (14 dpi) or in uninoculated leaves (21 dpi) (Fig. 2). In contrast, all NT-plants supported virus accumulation in both inoculated and uninoculated leaves (Fig. 2). These results were consistent with previous results $(11,33)$. Unexpectedly, in $\Delta \mathrm{A}^{\prime}$-plants inoculated with GINV, some plants allowed virus accumulation in inoculated leaves (Fig. 2, $\Delta \mathrm{A}^{\prime}$ plants 1,2 , and 8 ), but others did not. However, virus accumulation was never found in uninoculated leaves, even when the plants supported virus accumulation in inoculated leaves (Fig. 2). The experiment was repeated three times and the results were essentially identical. The analysis by a direct tissue immunoblotting using an anti-GINV antiserum also indicated that GINV was detected as spots on inoculated leaves in some $\Delta \mathrm{A}^{\prime}$-plants, but never in uninoculated leaves in all plants (Fig. 3). GINV was detected in both inoculated and uninoculated leaves in NT-plants. No virus accumulation was found in either inoculated or uninoculated leaves of P50- and $\Delta$ A-plants (Fig. 3). In the case of $\Delta \mathrm{C}$-plants, small spots were sometimes detected only in inoculated leaves of some plants (Fig. 3). However, virus accumulation in inoculated leaves of $\Delta \mathrm{C}$-plants was below the level of detection by ELISA.

Inhibition of long-distance movement of GINV in transgenic plants expressing $\Delta \mathbf{A}^{\prime}$. To examine virus distribution within NT and transgenic plants inoculated with GINV, leaf blades, midribs, and petioles of inoculated leaves at $14 \mathrm{dpi}$ and uninoculated leaves at $21 \mathrm{dpi}$ were analyzed by a tissue blot hybridization analysis. Stems at 21 dpi cut from the plants were also subjected to hybridization analysis. In NT-plants, strong hybridization signals were found in leaf blades, midribs, and petioles of both inoculated and uninoculated leaves, and in stems (Fig. 4). No signals were detected from any leaf tissues and stems of P50- and $\triangle \mathrm{A}$-plants inoculated with GINV. The results coincided with those obtained from ELISA and the direct tissue immunoblot analysis described above.

When tissue samples from $\Delta \mathrm{A}^{\prime}$-plants inoculated with GINV were analyzed, positive signals were found in inoculated leaves of 7 of 10 inoculated plants (Fig. 4, plants 1 and 5 to 10). In one particular plant (plant 7), strong signals with almost the same intensity as those of NT-plants were found in the leaf blade and midrib of an inoculated leaf. In this experiment, GINV was detected in midribs from only two plants (plants 5 and 7), and in petioles from three plants (plants 5, 7, and 9). The signals from petioles of inoculated leaves were weak compared with those from NTplants. Our attempts to detect GINV in stems or in tissues of uninoculated leaves of $\Delta \mathrm{A}^{\prime}$-plants failed including plant 7 , which showed strong hybridization signals from its inoculated leaves (Fig. 4). These results indicated that in some $\Delta \mathrm{A}^{\prime}$-plants, GINV could spread by cell-to-cell movement within inoculated leaves, but long-distance movement from inoculated leaves to uninoculated leaves was completely inhibited.

GINV distribution in inoculated leaves of transgenic plants expressing $\Delta \mathbf{A}^{\prime}$. We next investigated the distribution of GINV in leaf tissues of NT-, P50-, and $\Delta \mathrm{A}^{\prime}$-plants by an immunohistochemical analysis using an anti-GINV antiserum. Samples for thin sections were prepared from leaf blades, midribs, and petioles of inoculated leaves at 7 and $14 \mathrm{dpi}$ and of uninoculated leaves at $21 \mathrm{dpi}$. In cross sections of leaf blades from NT-plant leaves at $7 \mathrm{dpi}$, GINV was already distributed in the epidermal cells and palisade and spongy parenchyma cells (Fig. 5A) and in bundle sheath cells and phloem cells in minor veins (class IV) of $N$. occidentalis leaves (Fig. 5F). In cross sections from midribs of NT-plant leaves at $14 \mathrm{dpi}$, a strong immunostaining signal was often detected in vascular bundle cells near abaxial phloem (Fig. $5 B$ ). In uninoculated leaves at $21 \mathrm{dpi}$, virus was detected from leaf mesophyll cells, bundle sheath cells and phloem cells in minor veins, and vascular bundle cells of midribs and petioles (data not shown). In contrast, no signals were found in any types of tissues from inoculated and uninoculated leaves of P50-plants (data not shown).

In the analysis of inoculated leaves of $\Delta \mathrm{A}^{\prime}$-plants, GINV accumulation was first verified by direct tissue immunoblotting of half-leaves, and then the opposite half-leaves were fixed for immunohistochemical analysis. In the inoculated leaves of $\Delta \mathrm{A}^{\prime}-$

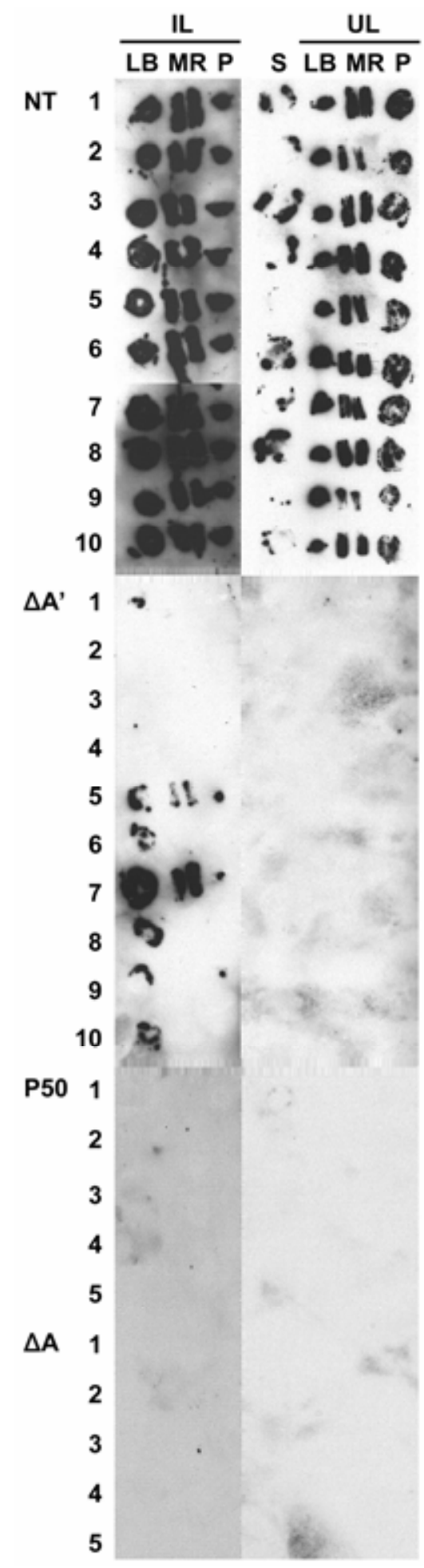

Fig. 4. Tissue blot hybridization analyses of nontransgenic (NT) and transgenic Nicotiana occidentalis plants expressing $\Delta \mathrm{A}^{\prime}, \mathrm{P} 50$, and $\Delta \mathrm{A}$ inoculated with Grapevine berry inner necrosis virus (GINV). Leaf blades (LB), midribs (MR), and petioles (P) of inoculated leaves (IL) at 14 days postinoculation (dpi) and upper uninoculated leaves (UL) at $21 \mathrm{dpi}$, and stems (S) immediately above IL at 21 dpi were analyzed using a negative-stranded RNA probe of GINV genome. Numbers indicate each individual plant inoculated with GINV. 
plants at $7 \mathrm{dpi}$, virus-specific signals were found in palisade and spongy parenchyma cells and in bundle sheath cells of minor veins (Fig. 5C). Immunostaining signals were also found in bundle sheath cells near abaxial phloem in midribs of inoculated leaves at 14 dpi (Fig. 5D), which was consistent with virus distribution in NT-plant leaves. Extensive observation of leaf minor veins at 14 dpi showed that immunostaining signals were found in phloem cells as well as in the surrounding bundle sheath cells (Fig. 5G, H, and I). The immunostained cells were determined to be phloem parenchyma cells based on cross sections of minor vein (class IV) of a healthy leaf (Fig. 4E) and previous criteria $(6,29)$. The percentage of phloem parenchyma cells containing signals out of minor veins in which bundle sheath cells were infected with GINV was 54\% (7 out of 13 phloem cells examined).

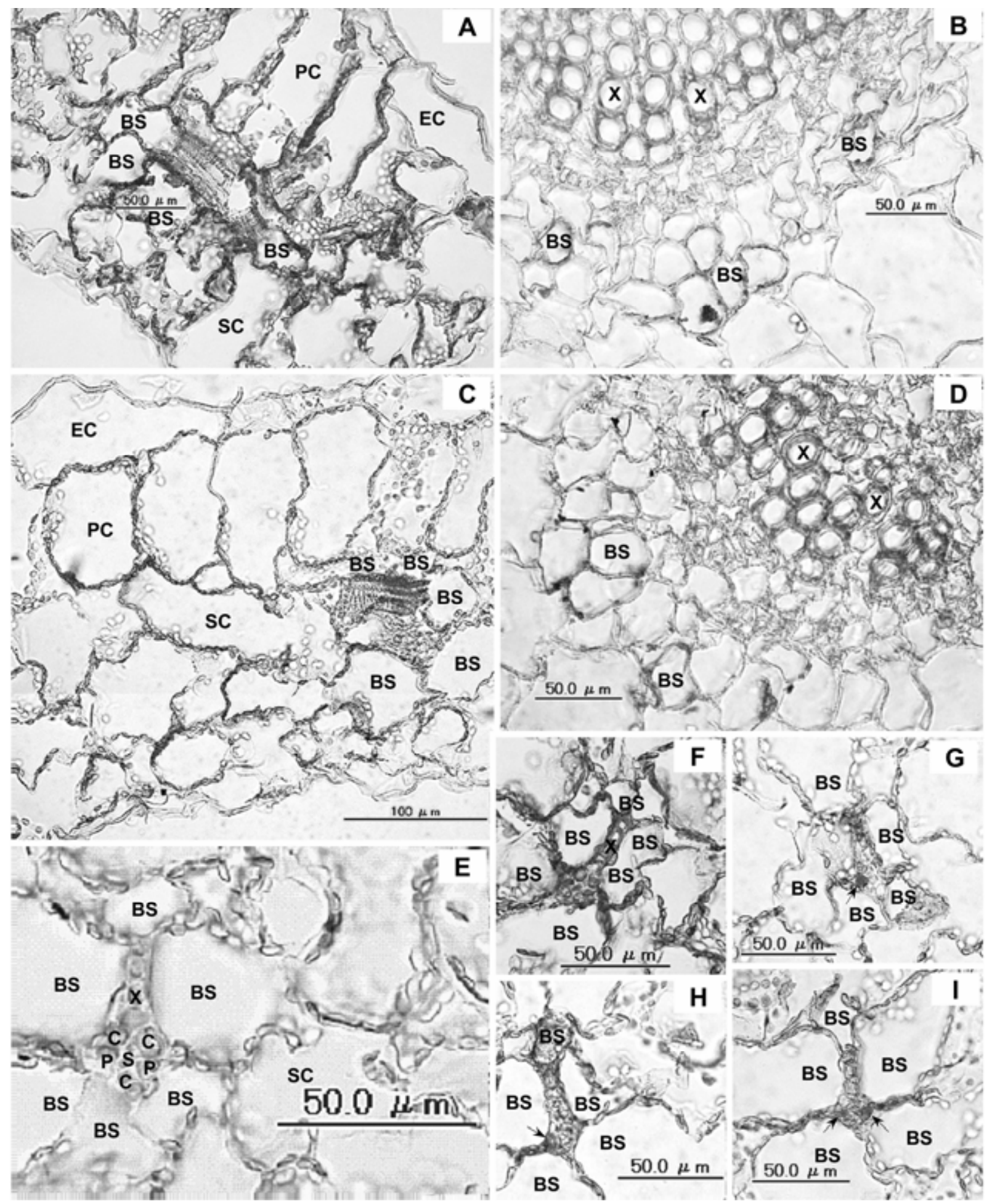

Fig. 5. Immunohistochemical analyses of leaves of nontransgenic (NT) and transgenic ( $\left.\Delta \mathrm{A}^{\prime}\right)$ Nicotiana occidentalis plant leaves inoculated with Grapevine berry inner necrosis virus (GINV) using an anti-GINV antiserum. A, A thin section of leaf blade of an NT plant at 7 days postinoculation (dpi) showing the staining signals of virus infection in epidermal cells (EC), palisade parenchyma cells (PC), bundle sheath cells (BS), and spongy parenchyma cells (SC). B, A thin section of midrib from an NT plant (14 dpi) showing the staining signals of virus infection in BS. C and D, Thin sections of leaf blade (7 dpi) and midrib (14 dpi) of $\Delta \mathrm{A}^{\prime}$ plants, respectively, showing the staining signals of virus infection in PC, SC, and BS. E to I, Cross section of minor vein (class IV) of a healthy leaf (E), an inoculated leaf of NT plant at $7 \mathrm{dpi}(\mathbf{F})$, and inoculated leaves of $\Delta \mathrm{A}^{\prime}$ plants at $14 \mathrm{dpi}(\mathbf{G}, \mathbf{H}$, and I). Arrows in $\mathbf{G}, \mathbf{H}$, and $\mathbf{I}$ indicate the staining signals of virus infection in phloem parenchyma cells. $\mathrm{C}$, companion cells; $\mathrm{P}$, phloem parenchyma cells; $\mathrm{S}$, sieve elements; $\mathrm{X}$, xylem. 
The results indicated that GINV could enter into phloem parenchyma cells from the surrounding bundle sheath cells in inoculated leaves. No immunostaining signals were detected in leaf blade, midribs, and petioles of upper uninoculated leaves of $\Delta \mathrm{A}^{\prime}$ plants at 21 dpi (data not shown).

Accumulation and localization of P50 in sieve elements of transgenic and ACLSV-infected plant leaves. We previously re-

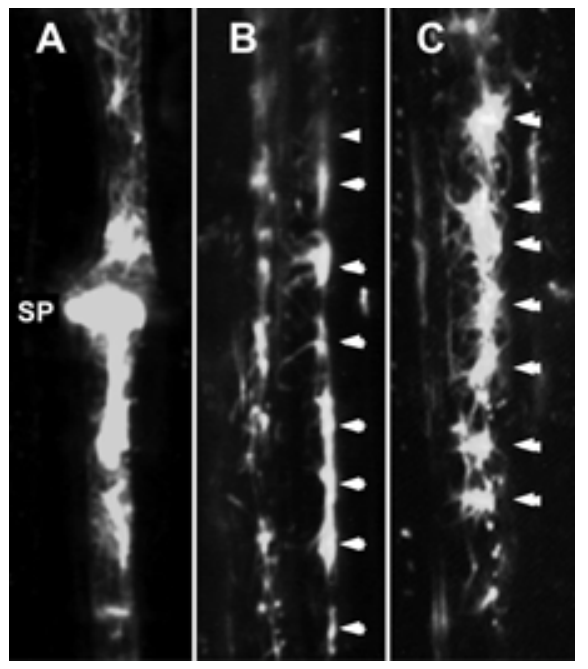

Fig. 6. Detection of fluorescence in sieve elements (A to C) of transgenic Nicotiana occidentalis leaves expressing P50 fused to green fluorescent protein by a confocal laser scanning microscope. Arrowheads in $\mathbf{B}$ and $\mathbf{C}$ indicate clusters of intense fluorescence thought to be located in plasmodesmata connecting sieve element and companion cells. SP, sieve plate. ported that P50-EGFP fusion accumulated in sieve elements (SE) and formed an extensive interconnecting network of threadlike structure in transgenic plants (35). P50-EGFP was also heavily associated with sieve plates (Fig. 6A). More detailed observation of leaf veins showed that P50-EGFP fluorescence is associated with the parietal layer of SE and clusters of intense fluorescence interconnected by threadlike structures, which were located at almost regular intervals (Fig. $6 \mathrm{~B}$ and $\mathrm{C}$ ). The localization of an $\mathrm{MP}$ in SE is reported for Cucumber mosaic virus 3 a (CMV-3a)GFP fusion protein (3).

The localization of P50 and its truncated derivatives in SE of transgenic $N$. occidentalis and ACLSV-infected $C$. quinoa plants was also investigated by immunogold electron microscopy using an anti-P50 antiserum. In P50-plant leaves, gold particles were often found on the parietal layer of SE (Fig. 7A and B) and on sieve plates (Fig. 7E). Gold particles were also observed in the inside of SE as small aggregates (Fig. 7C and D), but were not found on P-protein in SE. Similar localization of gold particles were observed in phloem cells of $\Delta \mathrm{A}^{\prime}-$ and $\Delta \mathrm{A}$-plants and ACLSV-infected $C$. quinoa plants (Fig. 7F). Thus, the accumulation and distribution of P50 in SE of transgenic and infected leaves almost coincided with those of P50-GFP examined by a confocal laser scanning microscope.

\section{DISCUSSION}

Analyses of P50- and $\Delta \mathrm{A}$-plants inoculated with GINV by direct tissue immunoblotting and tissue blot hybridization indicated that no virus was detected in either inoculated or uninoculated leaves of inoculated plants. These results reconfirm the previous results obtained by ELISA $(11,33)$. Some of the $\Delta \mathrm{A}^{\prime}$-plants supported the accumulation of GINV in inoculated leaves, though
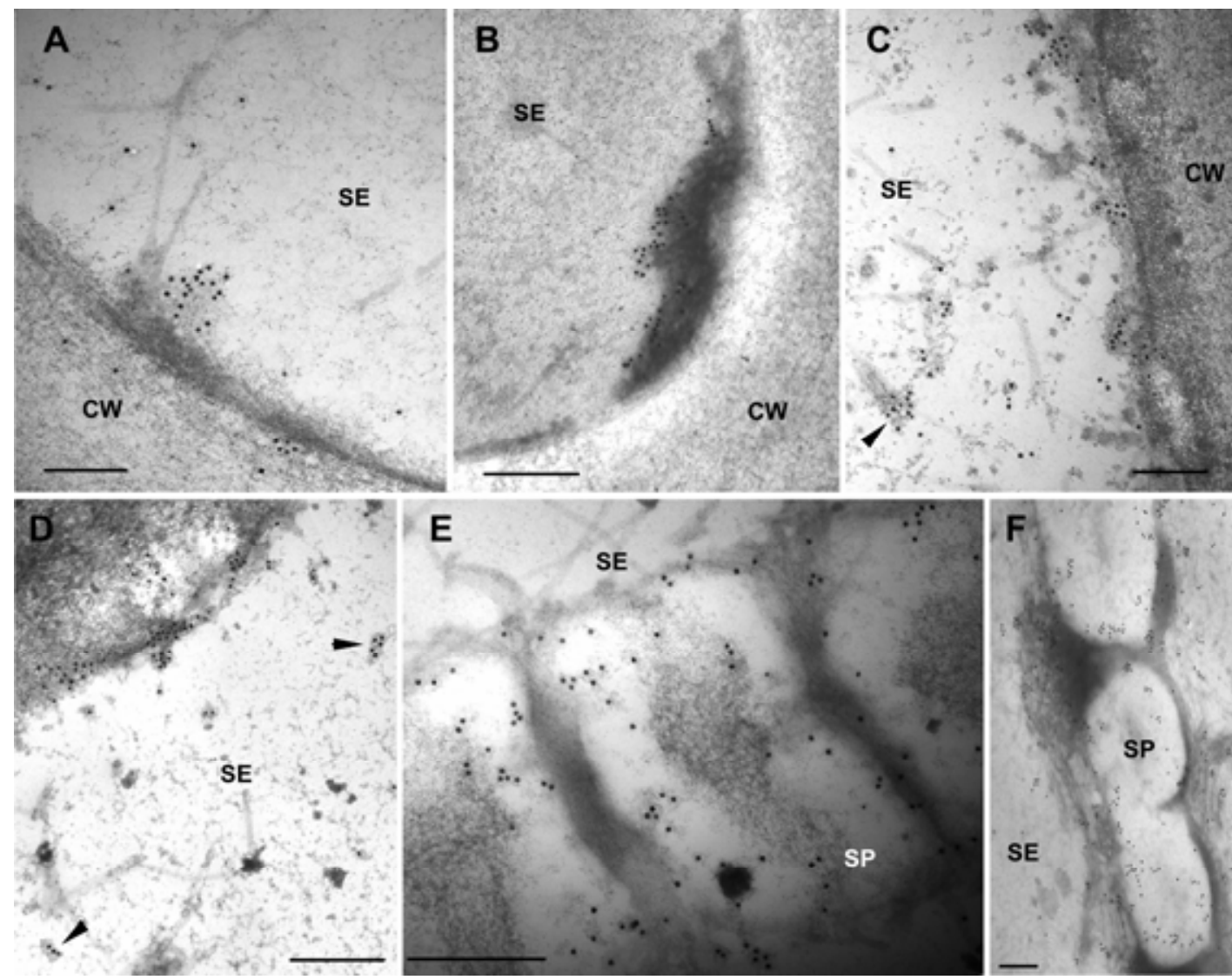

Fig. 7. Immunoelectron microscopy of transgenic Nicotiana occidentalis leaves expressing P50 (A to E) and Chenopodium quinoa leaf infected with Apple chlorotic leaf spot virus (ACLSV) (F) using an anti-P50 antiserum. Gold particles were observed on the parietal layer of sieve elements (SE) (A and B) and in the inside of SE (arrowheads in C and D). Gold particles were also located on sieve plates of P50 plant and ACLSV-infected plant (E and F). CW, cell wall; SP, sieve plate. 
virus spread was reduced in comparison with that in NT-plants. However, long-distance movement from inoculated leaves to uninoculated leaves was completely inhibited in these $\Delta \mathrm{A}^{\prime}$-plants. At present, we are not able to explain why only $\Delta \mathrm{A}^{\prime}$-plants permit virus spread in inoculated leaves, because the number of deleted amino acids of $\Delta \mathrm{A}^{\prime}(\Delta 416-457)$ is fewer than that of $\Delta \mathrm{A}(\Delta 395$ 457). Immunoblot analysis did not show large differences in the amount of expressed proteins among P50-, $\Delta \mathrm{A}^{\prime}-$, and $\Delta \mathrm{A}$-plant leaves (Fig. 1). It is also unknown why only some plants from the inoculated $\Delta \mathrm{A}^{\prime}$-plants were able to allow virus to spread in inoculated leaves and others did not. Immunoblot analysis showed that $\Delta \mathrm{A}^{\prime}$ protein was detected from both plants that allow GINV to accumulate in inoculated leaves and plants that do not allow GINV accumulation in inoculated leaves (Fig. 1C). Polymerase chain reaction analysis also showed that $\Delta \mathrm{A}^{\prime}$-transgene with the same size was amplified from both transgenic plants (data not shown).

Plant viruses which are replicated in initially infected cells spread from cell to cell in the epidermal and mesophyll cells, and then are capable of passage through bundle sheath, vascular parenchyma, and/or companion cells into SE for systemic movement $(4,16,17)$. The interfaces between nonvascular and vascular tissue appear to be a major barrier for systemic virus movement. In fact, the bundle sheath-phloem interface is known to be a barrier to entry into the phloem long-distance transport system for several virus-host combinations $(6,7,10,14,27,28,31,32)$. In $\Delta \mathrm{A}^{\prime}-$ plants, GINV could not be detected from stems immediately above inoculated leaves in which virus accumulation was found (Fig. 4), suggesting that blocking of GINV systemic movement might occur either at the bundle sheath-phloem interface or between phloem cells and SE (and/or within SE) in inoculated leaves. Immunohistochemical analysis of GINV-inoculated leaves of the plants expressing $\Delta \mathrm{A}^{\prime}$ showed that GINV could invade phloem parenchyma cells through bundle sheath of minor veins (Fig. 5), suggesting that the long-distance transport of GINV might be inhibited between phloem cells and SE and/or within SE rather than between the bundle sheath-phloem interfaces.

CMV-3a protein accumulated in the parietal layer of SE (3). The P50-EGFP fusion is also accumulated in SE and is associated with sieve plates in transgenic plant leaves (35). As shown in this study, GFP fluorescence was found on the parietal layer of SE and clusters of intense fluorescence were located at regular intervals (Fig. 6). The results were confirmed by immunogold electron microscopy of transgenic and infected plant leaves in which gold particles were often found on the parietal layer of SE and sieve plates (Fig. 7). As P50 itself has a specific activity for cell-to-cell trafficking (24), the proteins produced in the outside cells surrounding phloem cells and/or in the phloem parenchyma and companion cells may move into SE and are associated with the parietal layer of SE. Movement proteins in the parietal layer of SE may play a role to facilitate the long-distance movement of the virus in $\mathrm{SE}$.

P50 may bind to GINV-P39 directly or indirectly and interferes with the intracellular and intercellular trafficking of P39 in leaf epidermal cells (11). It therefore seems likely that the movement and function of P39 will be blocked by P50 on the parietal layer of SE, even if GINV could invade into phloem parenchyma cells, companion cells, and SE through bundle sheath in inoculated leaves of $\Delta \mathrm{A}^{\prime}$-plants. Consequently, virus trafficking within $\mathrm{SE}$ may be hindered in $\Delta \mathrm{A}^{\prime}$-plant leaves.

In this paper, we show that $\Delta \mathrm{A}^{\prime}$-plants inhibit the long-distance movement of GINV from inoculated leaves to uninoculated leaves. P50 expressed in transgenic plant leaves might not only interfere with the cell-to-cell movement of GINV, but might also block its systemic trafficking through SE. Even If GINV overcomes the inhibition of cell-to-cell movement in inoculated leaves as shown in $\Delta \mathrm{A}^{\prime}$ - and $\Delta \mathrm{C}$-plants (Fig. 3), the P50 accumulated on the parietal layer of SE can invalidate the functions of P39 and inhibit long-distance movement of the virus. This is why the resistance is highly effective and systemic movement of GINV was never observed in transgenic plants expressing P50. The mechanism described here will lead to the design of new virus resistance strategies in plants.

\section{ACKNOWLEDGMENTS}

This work was supported in part by a Grant-Aid for the 21st Century Center of Excellence Program from the Ministry of Education, Culture, Sports, Science and Technology of Japan.

\section{LITERATURE CITED}

1. Ares, X., Calamante, G., Cabral, S., Jodge, J., Hemenway, P., Beachy, R. N., and Mentaberry, A. 1998. Transgenic plants expressing potato virus X ORF2 protein (p24) are resistant to tobacco mosaic virus and $\mathrm{Ob}$ tobamoviruses. J. Virol. 72:731-738.

2. Beck, D. L., van Dolleweerd, C. J., Lough, T. J., Balmori, E., Voot, D. M., Andersen, M. T., O’Brien, I. E. W., and Forster, R. L. S. 1994. Disruption of virus movement confers broad-spectrum resistance against systemic infection by plant viruses with a triple gene block. Proc. Natl. Acad. Sci. USA 91:10310-10314.

3. Blackman, L. M., Boevink, P., Santa Cruz, S., Palukaitis, P., and Oparka, K. J. 1998. The movement protein of Cucumber mosaic virus traffics into sieve elements in minor veins of Nicotiana clevelandii. Plant Cell 10:525537.

4. Carrington, J. C., Kasschau, K. D., Mahajan, S. K., and Schaad, M. C. 1996. Cell-to-cell and long-distance transport of viruses in plants. Plant Cell 8:1669-1681.

5. Cooper, B., Lapidot, M., Heick, J. S., Dodds, J. A., and Beachy, R. N. 1995. A defective movement protein of TMV in transgenic plants confers resistance to multiple viruses whereas the functional analog increases susceptibility. Virology 206:307-313.

6. Ding, X. S., Shintaku, M. H., Arnold, S. A., and Nelson, R. S. 1995. Accumulation of mild and severe strains of tobacco mosaic virus in minor veins of tobacco. Mol. Plant-Microbe Interact. 8:32-40.

7. Ding, X. S., Shintaku, M. H., Carter, S. A., and Nelson, R. S. 1996. Invasion of minor veins of tobacco leaves inoculated with tobacco mosaic virus mutants defective in phloem-dependent movement. Proc. Natl. Acad. Sci. USA 93:11155-11160.

8. German, S., Candresse, T., Lanneau, M., Huet, J. C., Pernollet, J. C., and Dunez, J. 1990. Nucleotide sequence and genome organization of apple chlorotic leaf spot closterovirus. Virology 179:104-112.

9. German-Retana, S., Bergey, B., Delbos, R. P., Candresse, T., and Dunez, J. 1997. Complete nucleotide sequence of the genome of a severe cherry isolate of apple chlorotic leaf spot trichovirus (ACLSV). Arch. Virol. 142:833-841.

10. Goodrick, B. J., Kuhn, C. W., and Hussey, R. S. 1991. Restricted systemic movement of cowpea chlorotic mottle virus in soybean with nonnecrotic resistance. Phytopathology 81:1426-1431.

11. Isogai, M., Saitou, Y., Takahashi, N., Itabashi, T., Terada, M., Satoh, H., and Yoshikawa, N. 2003. The 50-kDa protein of Apple chlorotic leaf spot virus interferes with intracellular and intercellular targeting and tubuleinducing activity of the 39-kDa protein of Grapevine berry inner necrosis virus. Mol. Plant-Microbe Interact. 16:188-195.

12. Isogai, M., and Yoshikawa, N. 2005. Mapping the RNA binding domain on the Apple chlorotic leaf spot virus movement protein. J. Gen. Virol. 86:225-229.

13. Karyeija, R. F., Kreuze, J. F., Gibson, R. W., and Valkonen, J. P. T. 2000. Synergistic interactions of a potyvirus and a phloem-limited crinivirus in sweet potato plants. Virology 269:26-36.

14. Kobori, T., Ohki, S. T., and Osaki, T. 2000. Movement of Cucumber mosaic virus is restricted at the interface between mesophyll and phloem pathway in Cucumis figarei. J. Gen. Plant Pathol. 66:159-166.

15. Lapidot, M., Gafny, R., Ding, B., Wolf, S., Lucas, W. J., and Beachy, R. N. 1993. A dysfunctional movement protein of tobacco mosaic virus that partially modifies the plasmodesmata and limits virus spread in transgenic plants. Plant J. 4:959-970.

16. Leisner, S. M., and Howell, S. H. 1993. Long-distance movement of viruses in plants. Trends Microbiol. 1:314-317.

17. Lucas, W. J., and Gilbertson, R. L. 1994. Plasmodesmata in relation to viral movement within leaf tissues. Annu. Rev. Phytopathol. 32:387-411.

18. Malyshenko, S. I., Kondakova, O. A., Nazarova, J. V., Kaplan, I. B., Taliansky, M. E., and Atabekov, J. G. 1993. Reduction of tobacco mosaic virus accumulation in transgenic plants producing non-functional viral transport proteins. J. Gen. Virol. 74:1149-1156.

19. Martelli, G. P., Agranovski, A. A., Bar-Joseph, A. A., Boscia, D., Candresse, T., Coutts, R. H. A., Dolja, V. V., Duffus, J. E., Falk, B. W., 
Gonsalves, D., Jelkmann, W., Karasev, A. V., Minafra, A., Murant, A., Namba, S., Niblett, C. L., Vetten, H. J., and Yoshikawa, N. 2000. Genus Trichovirus. Pages 956-960 in: Virus Taxonomy. Seventh Report of the International Committee on Taxonomy of Viruses. M. H. van Regenmortel, C. M. Fauquet, and D. H. L. Bishop, eds. Academic Press, San Diego, CA.

20. Rajamaki, M.-L., and Valkonen, P. T. 2002. Viral genome-linked protein (VPg) controls accumulation and phloem-loading of a potyvirus in inoculated potato leaves. Mol. Plant-Microbe Interact. 15:138-149.

21. Rajamaki, M.-L., and Valkonen, P. T. 2003. Localization of a potyvirus and the viral genome-linked protein in wild potato leaves at an early stage of systemic infection. Mol. Plant-Microbe Interact. 16:25-34.

22. Sato, K., Yoshikawa, N., and Takahashi, T. 1993. Complete nucleotide sequence of the genome of an apple isolate of apple chlorotic leaf spot virus. J. Gen. Virol. 74:1927-1931.

23. Sato, K., Yoshikawa, N., Takahashi, T., and Taira, H. 1995. Expression, subcellular location and modification of the $50 \mathrm{kDa}$ protein encoded by ORF2 of the apple chlorotic leaf spot trichovirus genome. J. Gen. Virol. 76:1503-1507.

24. Satoh, H., Matsuda, H., Kawamura, T., Isogai, M., Yoshikawa, N., and Takahashi, T. 2000. Intracellular distribution, cell-to-cell trafficking and tubule-inducing activity of the $50 \mathrm{kDa}$ movement protein of Apple chlorotic leaf spot virus fused to green fluorescent protein. J. Gen. Virol. 81:2085-2094.

25. Seppanen, P., Puska, R., Honkanen, J., Tyulkina, L. G., Fedorkin, O., Morozov, S. Y., and Atabekov, J. G. 1997. Movement protein-derived resistance to triple gene block-containing plant viruses. J. Gen. Virol. 78:1241-1246.

26. Srinivasan, I., and Tolin, S. A. 1992. Detection of three viruses of clovers by direct tissue immunoblotting. Phytopathology 82:721.

27. Taliansky, M. E., and Garcia-Arenal, F. 1995. Role of cucumber capsid protein in long-distance movement within the infected plant. J. Virol. 69:916-922.
28. Thompson, J. R., and Garcia-Arenal, F. 1998. The bundle sheath-phloem interface of Cucumis sativus is a boundary to systemic infection by tomato aspermy virus. Mol. Plant-Microbe Interact. 11:109-114.

29. Turgeon, R., and Helper, P. K. 1989. Symplastic continuity between mesophyll and companion cells in minor veins of mature Cucurbita pepo L. leaves. Planta 179:24-31.

30. Verwoerd, T. C., Dekker, B. M. M., and Hoekewa, A. 1989. A small-scale procedure for the rapid isolation of plant RNAs. Nucleic Acids Res. $17: 2362$.

31. Wang, H.-L., Wang, Y., Giesman-Cookmeyer, D., Lommel, S. A., and Lucas, W. J. 1998. Mutations in viral movement protein alter systemic infection and identify an intercellular barrier to entry into the phloem long-distance transport system. Virology 245:75-89.

32. Wintermantel, W. M., Banerjee, N., Oliver, J. C., Paolillo, D. J., and Zaitlin, M. 1997. Cucumber mosaic virus is restricted from entering minor veins in transgenic tobacco exhibiting replicase-mediated resistance. Virology 231:248-257.

33. Yoshikawa, N., Gotoh, S., Umezawa, M., Satoh, H., Satoh, T., Takahashi, T., Ito, T., and Yoshida, K. 2000. Transgenic Nicotiana occidentalis plants expressing the 50-kDa protein of Apple chlorotic leaf spot virus display increased susceptibility to homologous virus, but strong resistance to Grapevine berry inner necrosis virus. Phytopathology 90:311-316.

34. Yoshikawa, N., Iida, H., Goto, S., Magome, H., Takahashi, T., and Terai, Y. 1997. Grapevine berry inner necrosis, a new trichovirus: Comparative studies with several known trichoviruses. Arch. Virol. 142:1351-1363.

35. Yoshikawa, N., Oogake, S., Terada, M., Miyabayashi, S., Ikeda, Y., Takahashi, T., and Ogawa, K. 1999. Apple chlorotic leaf spot virus $50 \mathrm{kDa}$ protein is targeted to plasmodesmata and accumulated in sieve elements in transgenic plant leaves. Arch. Virol. 144:2475-2483.

36. Yoshikawa, N., and Takahashi, T. 1988. Properties of RNAs and proteins of apple stem grooving and apple chlorotic leaf spot viruses. J. Gen. Virol. 69:241-245. 